\title{
Shelf Life of Chicken Meat Balls Submitted to Sous Vide Treatment
}

http://dx.doi.org/10.1590/1516-635x1702137-144

\section{-Author(s)}

Can ÖPI

Harun $\mathrm{F}^{\prime}$

University of Cumhuriyet, Faculty of Engineering, Department of Food, Sivas, Turkey

\section{Mail Address}

Corresponding author e-mail address Can ÖP

University of Cumhuriyet, Faculty of Engineering, Department of Food, Sivas, Turkey

E-mail:_opcan@cumhuriiyet.edu.tr ozlempelincan@gmail.com

\section{nKeywords}

Sous vide, chicken, meatballs, quality, shelf life.

\section{ABSTRACT}

The objective of this study was to investigate the appropriate temperature for processing storage of chicken meatballs made of minced chicken meat with the sous vide method. The chicken meatballs were prepared and separated into four experimental groups according to the application of heat treatment (10 and 20 minutes) and storage time $\left(+2\right.$ and $\left.+10^{\circ} \mathrm{C}\right)$. Sensory, microbiological (total aerobic mesophilic bacteria, total psychrotrophs, lactic acidbacteria, Enterobacteriaceae, Clostridiumperfringens, Listeria spp.), chemical ( $\mathrm{pH}$, thiobarbituric acid), color ( $L^{*}, a^{*}, b^{*}$ values), and texture profile analyses were performed on meatball samples. Cl. perfringens and Listeria spp. were not detected in meatball samples during the storage period. Samples cooked at 10 minute and stored at $+2^{\circ} \mathrm{C}$ the highest count of total aerobic mesophilic bacteria $(p<0.05)$. For lipid oxidation, interaction was observed between cooking time and storage temperature, with higher TBARs values for samples stored at $10^{\circ} \mathrm{C}$, while cooking time and storage temperature showed no influence on the color and textural analysis parameters. For the treatments evaluated, cooking time $x$ storage temperature seem affect more microbiological and chemical parameters than color and textural parameters of chicken meatballs.

\section{INTRODUCTION}

The positive effects of sufficient and balanced nutrition on mental development and job performance, increasing life span, and decreasing health risks have led to consumers to adopt the concept of well-balanced nutrition. Current changes in the food habits of individuals and recent advances in food processing technology have led to the emergence of fast foods of different varieties. Therefore, there is a trend in the food industry to research applications different from the conventional ways of consumption in line with the demands of the consumers. Food manufacturers are trying to increase the shelf life of the products, to present them with different taste and flavors, and to generate highly attractive foods using different food sources (Doğan et al., 2005).

Chicken meat is highly nutritious, lean, rich in proteins, and easy to digest. It is convenient because of its cheap price and as a substitute for red meat for consumption in high quantities. In addition, chicken meat is rich in $B$ vitamins $\left(B_{1}\right.$ and $\left.B_{6}\right)$ and iron. Furthermore, chicken is cheaper as well as healthier, with lower fat and cholesterol content, compared with red meat (Hasipek et al., 1991).

The sous vide method is the application of controlled cooking of the product vacuumed in a package at a determined temperature for a determined time (Gonzalez-Fandos et al., 2004). This application eliminates the risk of post-cooking contamination during packaging. 
Because the duration of the set temperature is under control in the sous vide method, the raw material keeps its nutritional value (Gonzalez-Fandos et al., 2004). In this study, changes during the preservation of chicken meatballs using the sous vide method were examined, aiming at extending the shelf life of the final product.

\section{MATERIAL AND METHOD}

\section{Preparation of chicken meatballs and sous vide application}

The chicken carcasses used as material in the study were supplied by a local processing plant (collected 8 hours after slaughter). The whole chicken carcasses brought to the laboratory were washed and drained. After skinning, the bones and the very fatty parts were removed and the meat and bones were separated. The meat was minced into 3-mm diameter pieces using a mincing machine. A condiment mixture consisting of $0.2 \%$ salt, $0.5 \%$ black pepper, $0.5 \%$ red pepper, $0.5 \%$ cumin, $6 \%$ onions, $4 \%$ garlic and $4 \%$ sunflower oil, relative to meat weight, was added to prepare meatball batter. These ratios were determined in a pre-test. After adding the mixture to the minced meat, meatballs with equal size and volume, weighing around $20 \mathrm{~g}$, were shaped in stainless steel ellipsisshaped molds (diameter: $6 \mathrm{~cm}$, height: $3 \mathrm{~cm}$ ). Meat balls were placed in plastic bags $(20 \times 30 \mathrm{~cm}$, made of nylon/ polyethylene, with heat resistance of $-40{ }^{\circ} \mathrm{C} /+120$ ${ }^{\circ} \mathrm{C}, \mathrm{O}_{2}$ permeability of $25-30 \mathrm{~cm}^{3} / \mathrm{m}^{2} / 24 \mathrm{~h}$, and water steam permeability of $5 \mathrm{~g} \mathrm{~m}^{2} / 24 \mathrm{~h}$ at $25^{\circ} \mathrm{C}$ ) containing an individual chicken meatball was heat sealed in a vacuum Turbovac packaging machine (Turbovac, UK).The highest vacuum level was set to $70 \%$. The experimental meatball samples were separated into two groups according to the duration of the heat treatment. Meatballs in vacuum bags were cooked in an ovenat $90{ }^{\circ} \mathrm{C}$ for 10 or 20 minutes. Core cooking temperatures of the chicken meatballs were measured in three different parts of the meatballs with a $\mathrm{K}$ probe thermocouple (Extech TM 100, U.S.A.) until constant temperature was reached (approximately 10 seconds). Vacuumed and cooked chicken meatballs were quickly cooled to $10^{\circ} \mathrm{C}$ core temperature in pack ice. Four experimental groups were established according to storage temperature $\left(2\right.$ or $\left.10^{\circ} \mathrm{C}\right)$ and heat treatment time (10 or $20 \mathrm{~min}$ ): $\mathrm{A}$, stored at $+2{ }^{\circ} \mathrm{C}$ after heat treatment for 10 minutes; $\mathrm{B}$, stored at $+10^{\circ} \mathrm{C}$ after heat treatment for 10 minutes; $\mathrm{C}$, stored at $+2^{\circ} \mathrm{C}$ after heat treatment for 20 minutes; and $D$, stored at +10 ${ }^{\circ} \mathrm{C}$ after heat treatment for 20 minutes. Samples were submitted to microbiological and chemical analyses on $0,7,14,28,42,56$, and 70 days of storage, and sensory analyses and color and texture measurements were performed on days $0,7,14,28$, and 42 . The study was repeated three times and the results were analyzed considering the average of three values. Each replicate consisted of approximately 250 packages of chicken meatballs.

\section{Microbiological analysis}

In order to determine bacterial counts, a 25-g meatball sample was weighed under aseptic conditions, $225 \mathrm{~mL}$ peptone water were added, and serial dilutions were prepared and seeded using the pour plate technique. Total mesophilic aerobic bacteria (TMAB) and total psychrotrophs count were determined using Plate Count Agar (PCA, Merck code 1.05463$)$, after incubation for 48 hours at $35^{\circ} \mathrm{C}$ and $7{ }^{\circ} \mathrm{C}$ for 10 days, respectively (Harrigan, 1998). Total lactic acid bacteria count (LAB) were determined using Man Rogosa Sharpe Agar (MRS, Merck) after incubation at $30{ }^{\circ} \mathrm{C}$ for 72 hours under anaerobic conditions (Harrigan, 1998). For Enterobacteriaceae counts, $1.0 \mathrm{~mL}$ sample was inoculated into $5 \mathrm{~mL}$ of molten $\left(45^{\circ} \mathrm{C}\right)$ Violet Red Bile Glucose Agar (Oxoid code CM 485). After setting, a $10 \mathrm{~mL}$ overlay of molten medium were added and incubation was carried out at $37^{\circ} \mathrm{C}$ for $24 \mathrm{~h}$. The large colonies with purple haloes were counted(5).In order to determine $\mathrm{Cl}$. perfringens count, sulfite polymyxin sulfadiazine (SPS, Merck) was added to the samples which were incubated at $37{ }^{\circ} \mathrm{C}$ for 48 hours under anaerobic conditions(6). In order to determine Listeria spp. count, samples were incubated at $30{ }^{\circ} \mathrm{C}$ for $24 \pm 2$ hours. Then $0.1-\mathrm{mL}$ pre-enrichment culture was added to $10 \mathrm{~mL}$ fully concentrated Fraser Broth medium for selective enrichment, and incubated at $35-37{ }^{\circ} \mathrm{C}$ for $48 \pm 2$ hours. After pre-enrichment, it was spread on Palcam agar (PA, Merck) with a loop, and plates were incubated at $30{ }^{\circ} \mathrm{C}$ for 48 hours (Halkman, 2005).

\section{Chemical analysis}

The $\mathrm{pH}$ value was recorded using a Crison Basic, model 20, pH meter. Chicken samples were thoroughly homogenized with $10 \mathrm{~mL}$ distilled water and the was homogenate used for $\mathrm{pH}$ determination (AOAC, 1990).

Thiobarbituric acid (TBA) was determined according to the method proposed by Pearson (1996). TBA 
content was expressed as milligrams of malonaldehyde (MA)/kg sample.

\section{Sensory analysis}

Sensory evaluation of the meatball groups included odor, crispiness, taste, appearance, and total assessment. To this aim, a specialized panelist group of eight people analyzed samples in terms of the given criteria. Scores were given according to a 1-5 scale, where 1 corresponded to very poor, 2 to poor, 3 to normal, 4 to good, and 5 to very good. Once the samples were evaluated, acceptability score was determined 2 (Kurtcan \& Gönül, 1987).

\section{Color measurement and texture profile analysis (TPA)}

Colorimetric measurements of samples were determined in triplicate using a colorimeter (Minolta spectrophotometer CM 3500d, Japan). The color reading includes lightness ( $\mathrm{L})$, redness (a), and yellowness (b). The equipment was standardized against a white color standard. Five replicate measurements were taken from each sample, following the guidelines for color measurements of the American Meat Science Association (Hunt \& Kropf, 1987 ).

Texture was determined using a Texture Analyzer (TA.XTPlus Stable Micro Systems, UK). Texture Profile Analysis (TPA) was used to determine hardness, cohesiveness, chewiness, and springiness (Bourne, 1978). This test was carried out using compression platen with $75 \mathrm{~mm}$ diameter. The average of five measurements each of hardness, cohesiveness, chewiness, and springiness was used for analyses.

\section{Statistical analysis}

Data were analyzed using the Statistical Analysis System (Version 6.1) package program. The values between groups, and within groups and between days were compared. Data were submitted to analysis of variance according to $3 \times 7 \times 4 \times 1$ factorial arrangement and in terms of fixed effects and inter-variable interactions to ensure "replicate number $x$ sampling time $x$ test groups $x$ number of samples examined at one instance from each test group". According to the General Linear Models procedure, the Fisher's smallest squares average (LSD) test was used to compare the means. Standard deviation of all averages were calculated (SAS Institute (1996)). The alpha value was determined as 0.05 .

\section{RESULTS}

\section{Results of Meatball Batter}

The TMAB count of the meatball batter was 4.3 $\log _{10} \mathrm{cfu} / \mathrm{g}$, psychrotrophs count was $3.6 \log _{10} \mathrm{cfu} / \mathrm{g}$, LAB count was $3.3 \log _{10} \mathrm{cfu} / \mathrm{g}$, Enterebacteriaceae $1.3 \log _{10} \mathrm{cfu} / \mathrm{g}$. Cl. perfiringes and Listeria spp. were not detected in the meatball batter. The $\mathrm{pH}$ value was determined as 6.5 and the TBA value was $0.33 \mathrm{mg}$ MDA/kg.

\section{Core Temperature Results of the Meatball Samples Obtained during Cooking}

Meatball samples prepared for the experiment were placed in an oven at $90{ }^{\circ} \mathrm{C}$. Since meatball samples were divided into two groups, according to cooking time, the cooking procedure was performed in two groups. The temperature of the meatball samples of the 10-min cooking group was measured at the $10^{\text {th }}$ minute in three different parts of the meatball, the average was calculated, and the core temperature was determined as $65.6^{\circ} \mathrm{C}$ at the end of 10 minutes. Again, the temperature of the meatball samples of the 20-minutes cooking group was measured at the $20^{\text {th }}$ minute in three different parts of the meatball, the average was calculated, and the core temperature was determined as $70.9^{\circ} \mathrm{C}$ at the end of 20 minutes.

\section{Results During the Storage}

The results of microbiological analysis of the meatball samples are given in Table 1. Cl. perfringens and Listeria spp. were not detected during the preservation period. At the end of heat treatment, the TMAB count was below the limit of detection until day 42 in Group $C$ samples and until day 7 in Group D samples (Table 1). TMAB count exceeded $10^{7}$ only in Group $B$ samples (Table 1). Psychrotrophcounts increased in the samples of Group A and B during storage and the highest value was determined in Group B samples (Table 1). Psychrotroph counts were below the limit of detection in $C$ and D Group of samples on days 0, 7 and 14, then increased to 3.7 and $3.9 \log _{10} \mathrm{cfu} / \mathrm{g}$, respectively, on the last day of storage. LAB count was determined as $1.8 \mathrm{cfu} / \mathrm{g}$ in Group A and B samples on day 0. LAB number was < $1.0 \log _{10} \mathrm{cfu} / \mathrm{g}$ in Group $\mathrm{C}$ samples during the storage period. The statistical evaluation of Enterobacteriaceae counts showed no significant difference $(p>0.05)$ between the samples of groups $A$ and $D$, whereas Group $B$ was significantly different $(p<0.05)$ from group $A$. Enterobacteriaceae were below the limit of detection during the storage period in Group C samples. 
Table 1 - Results of the microbiological analysis of chicken meatballs packed using the sous vide method $\left(\log _{10} \mathrm{cfu} / \mathrm{g}\right)$

\begin{tabular}{|c|c|c|c|c|c|c|c|c|c|}
\hline \multirow[b]{2}{*}{ Analysis } & \multirow[b]{2}{*}{ G } & \multicolumn{8}{|c|}{ Storage time (day) } \\
\hline & & $\mathrm{R}$ & $\begin{array}{c}0 \\
(\mathrm{M} \pm \mathrm{SD})\end{array}$ & $\begin{array}{c}7 \\
(\mathrm{M} \pm \mathrm{SD})\end{array}$ & $\begin{array}{c}14 \\
(\mathrm{M} \pm \mathrm{SD})\end{array}$ & $\begin{array}{c}28 \\
(\mathrm{M} \pm \mathrm{SD})\end{array}$ & $\begin{array}{c}42 \\
(\mathrm{M} \pm \mathrm{SD})\end{array}$ & $\begin{array}{c}56 \\
(\mathrm{M} \pm \mathrm{SD})\end{array}$ & $\begin{array}{c}70 \\
(\mathrm{M} \pm \mathrm{SD})\end{array}$ \\
\hline \multirow{4}{*}{ TMAB } & A & \multirow{4}{*}{$4.3 \pm 0.01$} & $1.8 \pm 0.01^{b}$ & $2.01 \pm 0.3^{b}$ & $2.8 \pm 0.2^{b}$ & $3.2 \pm 0.4^{\mathrm{ab}}$ & $3.9 \pm 0.3^{a, y}$ & $4.01 \pm 0.1^{a, y}$ & $4.9 \pm 0.3^{a, y}$ \\
\hline & B & & $1.8 \pm 0.01^{b}$ & $2.7 \pm 0.1^{b}$ & $3.9 \pm 0.3^{b}$ & $4.5 \pm 0.2^{b}$ & $5.9 \pm 0.1^{a, z}$ & $6.9 \pm 0.2^{a, z}$ & $7.4 \pm 0.2^{a, z}$ \\
\hline & C & & * & * & * & * & * & $3.3 \pm 0.1^{y}$ & $3.9 \pm 0.2^{y}$ \\
\hline & D & & * & * & $2.1 \pm 0.1^{b}$ & $3.9 \pm 0.2^{b}$ & $4.8 \pm 0.2^{a, z}$ & $5.6 \pm 0.2^{a, z}$ & $6.3 \pm 0.3^{a, z}$ \\
\hline \multirow{4}{*}{ Psychrotrops } & A & \multirow{4}{*}{$3.6 \pm 0.01$} & $2.3 \pm 0.01^{b}$ & $3.9 \pm 0.2^{\mathrm{a}}$ & $4.01 \pm 0.3^{a}$ & $4.13 \pm 0.1^{a, y}$ & $4.22 \pm 0.4^{a, y}$ & $4.39 \pm 0.3^{a, y}$ & $4.96 \pm 0.1^{a, y}$ \\
\hline & B & & $2.3 \pm 0.1^{c}$ & $4.6 \pm 0.1^{b}$ & $5.01 \pm 0.3^{a}$ & $5.3 \pm 0.1^{a, z}$ & $6.13 \pm 0.2^{a, z}$ & $6.81 \pm 0.1^{a, z}$ & $7.6 \pm 0.3^{a, z}$ \\
\hline & C & & * & * & * & $2.7 \pm 0.4^{x}$ & $3.01 \pm 0.3^{x}$ & $3.3 \pm 0.3^{x}$ & $3.7 \pm 0.4^{x}$ \\
\hline & D & & * & * & * & $2.9 \pm 0.2^{x}$ & $3.1 \pm 0.3^{x}$ & $3.6 \pm 0.1^{x}$ & $3.9 \pm 0.3^{x}$ \\
\hline \multirow{4}{*}{ LAB } & A & \multirow{4}{*}{$3.3 \pm 0.01$} & $1.8 \pm 0.1^{b}$ & $2.01 \pm 0.1^{b}$ & $2.3 \pm 0.1^{\mathrm{ab}}$ & $2.9 \pm 0.1^{a}$ & $3.3 \pm 0.1^{a, z}$ & $3.7 \pm 0.1^{a, z y}$ & $3.6 \pm 0.1^{a, y}$ \\
\hline & B & & $1.8 \pm 0.1^{b}$ & $2.2 \pm 0.1^{b}$ & $2.9 \pm 0.1^{\mathrm{ab}}$ & $3.6 \pm 0.1^{a}$ & $3.8 \pm 0.1^{a, z}$ & $4.3 \pm 0.1^{a, z}$ & $4.7 \pm 0.1^{a, z}$ \\
\hline & C & & * & * & * & * & * & * & * \\
\hline & D & & * & * & $2.3 \pm 0.1$ & $2.2 \pm 0.1$ & $2.7 \pm 0.1^{y}$ & $2.9 \pm 0.1^{y}$ & $3.01 \pm 0.1^{y}$ \\
\hline \multirow{4}{*}{ Enterobacteriaceae } & A & \multirow{4}{*}{$1.3 \pm 0.01$} & * & * & $1.5 \pm 0.1^{b}$ & $1.4 \pm 0.1^{b}$ & $1.7 \pm 0.2^{b}$ & $2.02 \pm 0.1^{a}$ & $2.3 \pm 0.1^{a, y}$ \\
\hline & B & & * & * & $1.8 \pm 0.1^{b}$ & $1.6 \pm 0.1^{b}$ & $2.3 \pm 0.2^{\mathrm{a}}$ & $2.7 \pm 0.1^{\mathrm{a}}$ & $3.02 \pm 0.1^{a, z}$ \\
\hline & C & & * & * & * & * & * & * & * \\
\hline & D & & * & * & * & * & * & $1.9 \pm 0.1$ & $2.01 \pm 0.1^{y}$ \\
\hline
\end{tabular}

a, b, c : Means within a row lacking a common superscript letter are different $(p<0.05) . \mathbf{x}, \mathbf{y}, \mathbf{z}$ : Means within a column lacking a common superscript letter are different ( $\mathrm{p}<0.05)$. *: Not analyzed $\left(<10^{1}\right)$. Each point is the mean of three samples taken from two replicate experiments (n: 3 x 2: 6). Error bars show SD. G: Groups, R: Raw fillet.

The results of the chemical analyses of the examined meatball samples are given in Table 2. During the evaluation of the samples, the $\mathrm{pH}$ of group $\mathrm{B}$ samples was significantly different $(p<0.05)$ among storage days. The values of TBA increased in groups $B$ and $D$ along the days of storage and reached 3.6 and $3.9 \mathrm{mg}$ MDA $/ \mathrm{kg}$ respectively on day 70 .

Table 2 - Result of chemical analyses of chicken meatballs packed using the sous vide method.

\begin{tabular}{|c|c|c|c|c|c|c|c|c|c|}
\hline \multirow[b]{2}{*}{ Analysis } & \multirow[b]{2}{*}{ G } & \multicolumn{8}{|c|}{ Storage time (day) } \\
\hline & & $\mathrm{R}$ & $\begin{array}{c}0 \\
(M \pm S D)\end{array}$ & $\begin{array}{c}7 \\
(\mathrm{M} \pm \mathrm{SD})\end{array}$ & $\begin{array}{c}14 \\
(\mathrm{M} \pm \mathrm{SD})\end{array}$ & $\begin{array}{c}28 \\
(\mathrm{M} \pm \mathrm{SD})\end{array}$ & $\begin{array}{c}42 \\
(\mathrm{M} \pm \mathrm{SD})\end{array}$ & $\begin{array}{c}56 \\
(M \pm S D)\end{array}$ & $\begin{array}{c}70 \\
(\mathrm{M} \pm \mathrm{SD})\end{array}$ \\
\hline \multirow{4}{*}{$\mathrm{pH}$} & A & \multirow{4}{*}{$6.5 \pm 0.1$} & $6.2 \pm 0.1$ & $6.2 \pm 0.1$ & $6.6 \pm 0.1$ & $6.8 \pm 0.1$ & $6.7 \pm 0.2$ & $7.01 \pm 0.3^{z}$ & $7.3 \pm 0.2^{z}$ \\
\hline & B & & $6.2 \pm 0.1^{b}$ & $6.3 \pm 0.1^{b}$ & $6.5 \pm 0.1^{b}$ & $6.4 \pm 0.2^{b}$ & $6.9 \pm 0.1^{a}$ & $7.2 \pm 0.2^{\mathrm{a}, \mathrm{z}}$ & $7.8 \pm 0.3^{a, z}$ \\
\hline & C & & $6.5 \pm 0.1$ & $6.2 \pm 0.2$ & $6.3 \pm 0.1$ & $6.2 \pm 0.1$ & $6.2 \pm 0.1$ & $6.3 \pm 0.1^{y}$ & $6.3 \pm 0.2^{y}$ \\
\hline & D & & $6.2 \pm 0.1$ & $6.4 \pm 0.1$ & $6.2 \pm 0.1$ & $6.3 \pm 0.2$ & $6.18 \pm 0.3$ & $6.5 \pm 0.2^{y}$ & $6.6 \pm 0.2^{y}$ \\
\hline \multirow{4}{*}{$\begin{array}{l}\text { TBA } \\
(1000 \mathrm{gMDA} / \mathrm{kg})\end{array}$} & A & \multirow{4}{*}{$0.33 \pm 0.1$} & $0.28 \pm 0.1^{b}$ & $0.46 \pm 0.1^{b}$ & $0.55 \pm 0.1^{b}$ & $0.91 \pm 0.1^{\mathrm{ab}, \mathrm{z}}$ & $0.83 \pm 0.1^{b, y}$ & $1.2 \pm 0.1^{\mathrm{a}, \mathrm{z}}$ & $1.5 \pm 0.1^{a, z y}$ \\
\hline & B & & $0.31 \pm 0.2^{c}$ & $0.63 \pm 0.2^{c}$ & $0.86 \pm 0.1^{c}$ & $1.15 \pm 0.3^{b, z}$ & $1.9 \pm 0.1^{b, z}$ & $2.2 \pm 0.2^{b, z}$ & $3.6 \pm 0.1^{a, z}$ \\
\hline & C & & $0.21 \pm 0.2$ & $0.32 \pm 0.1$ & $0.41 \pm 0.2$ & $0.51 \pm 0.2^{y}$ & $0.43 \pm 0.3^{y}$ & $0.9 \pm 0.1^{y}$ & $0.91 \pm 0.2^{y}$ \\
\hline & D & & $0.36 \pm 0.3^{b}$ & $0.49 \pm 0.1^{b}$ & $0.91 \pm 0.1^{b}$ & $1.09 \pm 0.2^{b, z}$ & $2.1 \pm 0.3^{a, z}$ & $2.7 \pm 0.1^{a, z}$ & $3.9 \pm 0.3^{\mathrm{a}, \mathrm{z}}$ \\
\hline
\end{tabular}

a, $\mathbf{b}, \mathbf{c}$ : Means within a row lacking a common superscript letter are different $(p<0.05) . \mathbf{x}, \mathbf{y}, \mathbf{z}$ : Means within a column lacking a common superscript letter are different $(p<0.05)$. Each point is the mean of three samples taken from two replicate experiments $(n: 3 \times 2: 6)$. Error bars show SD. G: Groups, R: Raw fillet. 
The findings of sensory analysis of the meatball samples are given in Table 3. During the overall evaluation of the parameters of sensory analysis, the best results were obtained by group A samples.

Table 3 - Result of sensory analysis of chicken ball with Sous vide method.

\begin{tabular}{|c|c|c|c|c|c|c|}
\hline \multirow{2}{*}{ Feature } & \multirow{2}{*}{ Group } & \multicolumn{5}{|c|}{ Storage Time (Day) } \\
\hline & & 0 & 7 & 14 & 28 & 42 \\
\hline \multirow{4}{*}{ Odor } & $A$ & $4.8 \pm 0.51^{a, z}$ & $4.5 \pm 0.52^{a, z}$ & $4.7 \pm 0.80^{a, z}$ & $4.8 \pm 0.23^{\mathrm{a}, \mathrm{z}}$ & $4.2 \pm 0.46^{a, z}$ \\
\hline & B & $4.8 \pm 0.63^{a, z}$ & $4 \pm 0.70^{a, z}$ & $4.3 \pm 0.59^{a, z}$ & $3.9 \pm 0.53^{a, z}$ & $3.5 \pm 0.23^{a, z}$ \\
\hline & C & $4 \pm 0.80^{a, z}$ & $3 \pm 0.70^{a, y}$ & $3.2 \pm 0.79^{a, y}$ & $2 \pm 0.41^{b, y}$ & $1 \pm 0.52^{c, y}$ \\
\hline & D & $4 \pm 0.59^{a, z}$ & $3 \pm 0.56^{a, y}$ & $3.4 \pm 0.96^{a, y}$ & $2 \pm 0.51^{b, y}$ & $1 \pm 0.82^{c, y}$ \\
\hline \multirow{4}{*}{ Crispiness } & A & $4.2 \pm 0.71^{a, z}$ & $4.3 \pm 0.61^{a, z}$ & $2.5 \pm 0.62^{b, y}$ & $2.1 \pm 0.38^{b, y}$ & $2.3 \pm 0.56^{b, y}$ \\
\hline & B & $4.2 \pm 0.66^{\mathrm{a}, \mathrm{z}}$ & $3.3 \pm 0.51^{a, z}$ & $2.6 \pm 0.71^{b, y}$ & $1 \pm 0.43^{c, x}$ & $1 \pm 0.73^{c, x}$ \\
\hline & C & $4.2 \pm 0.52^{\mathrm{a}, \mathrm{z}}$ & $3.8 \pm 0.63^{a, z}$ & $4 \pm 0.73^{a, z}$ & $4 \pm 0.61^{\mathrm{a}, \mathrm{z}}$ & $4.3 \pm 0.26^{a, z}$ \\
\hline & $\mathrm{D}$ & $4.2 \pm 0.43^{a, z}$ & $4 \pm 0.27^{a, z}$ & $2.5 \pm 0.42^{b, y}$ & $2 \pm 0.52^{b, y}$ & $2.2 \pm 0.28^{b, y}$ \\
\hline \multirow{4}{*}{ Taste } & $A$ & $4.5 \pm 0.31^{a, z}$ & $4.8 \pm 0.71^{\mathrm{a}, \mathrm{z}}$ & $4.2 \pm 0.56^{a, z}$ & $4.3 \pm 0.79^{a, z}$ & $4.9 \pm 0.33^{a, z}$ \\
\hline & B & $4.5 \pm 0.27^{a, z}$ & $3.8 \pm 0.63^{a, z}$ & $3.2 \pm 0.73^{a, z}$ & $2 \pm 0.63^{b, y}$ & $1 \pm 0.29 c, x$ \\
\hline & C & $3 \pm 0.39^{a, y}$ & $2.8 \pm 0.42^{a, y}$ & $3 \pm 0.42^{a, z}$ & $3.3 \pm 0.42^{a, z}$ & $3 \pm 0.58^{a, z}$ \\
\hline & D & $3 \pm 0.01^{a, y}$ & $2.4 \pm 0.36^{a, y}$ & $2.2 \pm 0.27^{\mathrm{a}, \mathrm{y}}$ & $2 \pm 0.33^{a, y}$ & $2 \pm 0.73^{a, y}$ \\
\hline \multirow{4}{*}{ Appearance } & $A$ & $4.2 \pm 0.51^{a, z}$ & $4 \pm 0.27^{a, z}$ & $4.4 \pm 0.56^{a, z}$ & $4.5 \pm 0.56^{a, z}$ & $4.4 \pm 0.39^{a, z}$ \\
\hline & B & $4.2 \pm 0.42^{\mathrm{a}, \mathrm{z}}$ & $4.2 \pm 0.81^{\mathrm{a}, \mathrm{z}}$ & $3.8 \pm 0.43^{a, z}$ & $2.8 \pm 0.61^{b, z y}$ & $1 \pm 0.52^{c, x}$ \\
\hline & C & $4 \pm 0.23^{a, z}$ & $3.8 \pm 0.72^{\mathrm{a}, \mathrm{z}}$ & $3 \pm 0.46^{a, z y}$ & $2 \pm 0.42^{b, y}$ & $2.2 \pm 0.28^{b, y}$ \\
\hline & $D$ & $4 \pm 0.32^{a, z}$ & $3 \pm 0.63^{a, y}$ & $2 \pm 0.53^{b, y}$ & $1 \pm 0.33^{c, x}$ & $1 \pm 0.37^{c, x}$ \\
\hline \multirow{4}{*}{$\begin{array}{l}\text { Total } \\
\text { Assessment }\end{array}$} & $A$ & $4.6 \pm 0.70^{a, z}$ & $4.8 \pm 0.76^{a, z}$ & $4.6 \pm 0.56^{a, z}$ & $4 \pm 0.29^{a, z}$ & $4 \pm 0.33^{a, z}$ \\
\hline & B & $4.6 \pm 0.061^{b, z}$ & $3 \pm 0.53^{a b, y}$ & $3.2 \pm 0.71^{a, z}$ & $2.8 \pm 0.33^{b, z y}$ & $1 \pm 0.57^{c, x}$ \\
\hline & $C$ & $3 \pm 0.53^{a, y}$ & $3.4 \pm 0.74^{a, z y}$ & $3.1 \pm 0.26^{a, z y}$ & $3 \pm 0.56^{a, z}$ & $2 \pm 0.46^{b, y}$ \\
\hline & D & $3 \pm 0.41^{\mathrm{a}, \mathrm{y}}$ & $3 \pm 0.13^{a, y}$ & $2 \pm 0.36^{b, y}$ & $2 \pm 0.21^{b, y}$ & $1 \pm 0.61^{c, x}$ \\
\hline
\end{tabular}

$a, b, c$ : Means within a row lacking a common superscript letter are different $(p<0.05) . x, y$, $z$ : Means within a column lacking a common superscript letter are different $(p<0.05)$. Each point is the mean of three samples taken from two replicate experiments ( $n: 3 \times 2: 6)$. Error bars show SD. 1: Very poor, 2: Poor, 3: Normal, 4: Good, 5: Very Good.

Color measurements were performed on the mentioned days of analysis and no changes were detected in $L^{*}, a^{*}$, or $b^{*}$ values during storage days within groups. Since the values obtained were very close to each other in the triplicate measurements and on each day of analysis, the average of all values are given in Table 4. This was also observed for texture results, and therefore, only average values are shown in Table 5.
Table 4 - Color properties of experimental chicken meatballs.

\begin{tabular}{cccc}
\hline Group & $\mathrm{L}^{*}$ & $\mathrm{a}^{*}$ & $\mathrm{~b}^{*}$ \\
\hline \multicolumn{3}{c}{$\mathrm{M} \pm \mathrm{SD}$} \\
\hline A & $73.24 \pm 0.42$ & $0.93 \pm 0.06$ & $17.42 \pm 0.56$ \\
\hline B & $73.88 \pm 0.29$ & $0.91 \pm 0.05$ & $17.13 \pm 0.44$ \\
\hline C & $72.81 \pm 0.38$ & $0.90 \pm 0.02$ & $17.56 \pm 0.39$ \\
\hline D & $72.39 \pm 0.46$ & $0.96 \pm 0.04$ & $17.49 \pm 0.54$
\end{tabular}


Table 5 - Textural properties of experimental chicken meatballs.

\begin{tabular}{ccccc} 
Group & $\begin{array}{c}\text { Hardness } \\
(\mathrm{kg})\end{array}$ & $\begin{array}{c}\text { Cohesiveness } \\
(\mathrm{mm} / \mathrm{mm})\end{array}$ & $\begin{array}{c}\text { Springiness } \\
(\mathrm{mm} / \mathrm{mm})\end{array}$ & $\begin{array}{c}\text { Chewiness } \\
(\mathrm{kg} / \mathrm{mm})\end{array}$ \\
\hline \multicolumn{5}{c}{$\mathrm{M} \pm \mathrm{SD}$} \\
\hline A & $5.69 \pm 0.22$ & $0.63 \pm 0.01$ & $13.21 \pm 0.44$ & $52.33 \pm 1.69$ \\
\hline B & $5.67 \pm 0.19$ & $0.67 \pm 0.04$ & $13.11 \pm 0.46$ & $50.21 \pm 1.41$ \\
\hline C & $5.53 \pm 0.28$ & $0.59 \pm 0.02$ & $13.26 \pm 0.51$ & $51.56 \pm 1.79$ \\
\hline D & $5.49 \pm 0.32$ & $0.61 \pm 0.04$ & $13.35 \pm 0.48$ & $52.19 \pm 1.82$ \\
\hline
\end{tabular}

\section{DISCUSSION}

The microbiological values are important criteria for meat and meat product quality (Nyati, 2000). The TMAB count determined in the meatball batter was $4.3 \log _{10} \mathrm{cfu} / \mathrm{g}$. This value is below the limit determined by ICMSF (1978) $\left(10^{7} \log _{10} \mathrm{cfu} / \mathrm{g}\right)$. In a study, chicken drumsticks were cooked for $2 \mathrm{~min}$ at $70^{\circ} \mathrm{C}$, reducing total plate counts from $10^{7} \mathrm{cfu} / \mathrm{g}$ to $<10 \mathrm{cfu} / \mathrm{g}$ in processed samples, which is close to the results of the present study (Nyati, 2000). Group B samples reached a value of $7.4 \log _{10} \mathrm{cfu} / \mathrm{g}$ and exceeded the limit value specified by ICMSF (1978) at the end of the storage period, because the TMAB group of microorganisms are able to reproduce at $10^{\circ} \mathrm{C}$. Similar conditions were also observed in Group D samples. These results are consistent with the findings of Light et al. (1988) and Schafheitle \& Light (1989), who stored sous vide chicken ballotine, chicken à la king, and courgette samples at $0-3^{\circ} \mathrm{C}$ for 21 days and obtained maximum total plate counts of only $8 \times 10^{2,9 \times 101}$ and $<10 \mathrm{cfu} / \mathrm{g}$, respectively. Another study reported that the TMAB count in chicken drumsticks stored using the sous vide method ( 2 minutes at $70{ }^{\circ} \mathrm{C}$ core temperature) was below the limit of detection at the end of five weeks of storage (Nyati, 2000). Spoilage was also rapid in group $B$ and $D$ (storage $10^{\circ} \mathrm{C}$ ) samples, where TMAB counts reached 7.4 and $6.3 \log _{10} \mathrm{cfu} / \mathrm{g}$, respectively, on day 70 , with resulting off-odors (Table 1 ).

The counts of psychrotrophs were lower than that of mesophilic bacteria, and were only detectable after 14 days of storage, except in group A and B samples. Psychrotroph count of group B samples was6.13 $\log _{10} \mathrm{cfu} / \mathrm{g}$ on the $42^{\text {nd }}$ day, exceeding the allowed limit. These low psychrotroph counts had also been observed by other authors (Rosnes et al., 1999). Psychrotrophs optimal growth is at $25^{\circ} \mathrm{C}$ (Halkman, 2005). Our results are in agreement with those reported by Gonzalez et al. (2004), who obtained a psychrotrophs count of $<1 \mathrm{cfu} / \mathrm{g}$ in fish samples heat-treated at $90{ }^{\circ} \mathrm{C}$ for 3.3 minutes, and $3 \log _{10} \mathrm{cfu} / \mathrm{g}$ at $+2{ }^{\circ} \mathrm{C}^{\prime}$ at the end of 45 days.

Acidification caused by lactic acid bacteria can affect the sensory quality of sous vide cooked meatbased dishes (Carlin, 1999). Simpson et al. (1994) found lactic acid bacteria counts above $3 \mathrm{log} \mathrm{cfu} / \mathrm{g}$ in sous vide meat sauce $\left(65^{\circ} \mathrm{C} / 15 \mathrm{~min}\right.$ and $75^{\circ} \mathrm{C} / 37$ min; 40 days at $5^{\circ} \mathrm{C}$ ). Rosnes et al. (1999) stored the products treated with the sous vide method at $+2{ }^{\circ} \mathrm{C}$ and reported that $L A B$ counts were below the limit of detection at the end of 45 days. This finding supports the results of the present study. In another study, $L A B$ counts were below the limit of detection in the cooked food treated with the sous vide method and stored at $+10^{\circ} \mathrm{C}$ in the beginning, but these counts increased during the following days of storage (Guerzoni et al., 1999). This finding supports the $L A B$ count findings obtained in group D samples. Lactic acid bacteria are able to replicate in vacuum-packed products. However, storage temperature affects $L A B$ and a decline in the growth was reported at low temperatures (Halkman, 2005).

Preservation temperature influences the growth of Enterobacteriaceae, as well as the heat treatment period. In a study with chicken briskets and drumsticks using the sous vide method and storage at $+2{ }^{\circ} \mathrm{C}$, Enterobacteriaceae count was below the limit of detection the end of five weeks (Schafheitle \& Light, 1989). In contrast, in the present study, Enterobacteriaceae were not detected during the storage time of 70 days in group C samples. In another study, the sous vide method was applied to fish fillets and the $2.2 \log _{10} \mathrm{cfu} / \mathrm{g}$ value determined in raw fillets was below the limit of detection in the samples stored at $+2{ }^{\circ} \mathrm{C}$ after the treatment, $2.84 \log _{10} \mathrm{cfu} / \mathrm{g}$ after 45 days in the samples stored at $+10^{\circ} \mathrm{C}$ (Gonzalez et al., 2004).

According to the data of the Microbiological Criteria Directive of Turkish Codex (Türk Gıda Kodeksi, 2009a), L. monocytogenes must not be present in $25 \mathrm{~g}$ of meat and meat products. In a study carried out in Turkey, Listeria species were investigated in 100 chicken samples and it was reported that $17 \%$ of the chicken meat contained Listeria spp (Çiftçioğlu, 1992). Listeria spp. and $\mathrm{Cl}$. perfringens are of great importance in poultry and ready-to-eat foods. Listeria spp. are a group of microorganisms destroyed of pasteurization, but they self-perpetuate at $+4{ }^{\circ} \mathrm{C}$ when heat treatment is insufficient. In the studies performed by various 
researchers on the products produced with the sous vide method, no detection of $\mathrm{Cl}$. perfringensor Listeria species was reported (Gonzalez et al., 2004; Nyati, 2000). In addition, according to Roldan et al. (2012), Listeria spp. and Cl. spp counts were no detectable or were lower than log $1 \mathrm{cfu} / \mathrm{g}$ in sous vide applications after $6,12,24 \mathrm{~h}$ at 60,70 and $80^{\circ} \mathrm{C}$.

The $\mathrm{pH}$ value and microorganism activities are closely related (Erol, 2007). A study reported that no significant changes were observed in the $\mathrm{pH}$ value of a pork loin treated with the sous vide method (Diaz et al., 2008). TBA value is a measure of the oxidative degradation in foods and 0.5-2 mg MDA/kg have been described in sous vide meat-based dishes (Grigioni et al., 2000). Lipid oxidation can cause rancidity in meat products. Consumers are unlikely to detect these off-flavors in meat products at TBA values below a threshold of about 0.5 MDA/kg (Grayl et al., 1987). According to Wang et al. (2004), in chicken wings treated with the sous vide method and stored at +2 ${ }^{\circ} \mathrm{C}$, the TBA value was below $2 \mathrm{mg}$ MDA $/ \mathrm{kg}$ at the end of the $7^{\text {th }}$ week.

The descriptive data of the chicken meatball samples indicated that changes occurred in product characteristics during storage. Assessments of the taste of the product varied significantly $(p<0.01)$ with storage time. Consumers preferred the day 0 product to the day 42 product in group B samples, but no differences were observed in A samples. The results of the present study therefore indicate that a sous vide chicken meatball can be stored for 42 days at $2^{\circ} \mathrm{C}$ and present acceptable sensory quality. The results of this study are supported by those obtained from the assessment of sous vide and other enhanced cook-chill chicken based products, particularly those containing a sauce component. Sous vide chicken a la king (Light et al., 1988), chicken ballotine (Schafheitle \& Light, 1989), and chicken noodles in sauce (Cremer et al., 1985) are reported to retain sensory quality and consumer acceptance for 14, 21 and 28 days respectively. These studies suggest that a sauce component can mask changes in the sensory characteristics of sous vide meat products. Hence, the sauce component and the considerable content of herbs and spices in the chicken meatballs evaluated in the present study could explain why it remained acceptable for a longer period than other similar products reported in the literature.

The results of the color measurement were very close to each other among the groups and days within a group. This may be due to the preparation of a single mixture of meatball batter for all groups. It was reported that the changes in color measurements are related to the components of the meatball batter and to the ratio of these components (Diaz et al., 2008).

Texture analysis of the meatball samples did not detect any differences among groups or days within a group. No data on the textural properties of sous vide cooked meat related storage time were found in literature. The sensory analysis was crucial for detecting texture changes as a function of storage temperature of sous vide cooked chicken meatballs, which became softer and flakier. This would mainly correspond to the protein degradation caused by chemical and enzymatic activity. Although heating at $70{ }^{\circ} \mathrm{C}$ inactivates part of the muscle proteases, residual protease activity continues in the refrigerated product. For example, heating up to $90^{\circ} \mathrm{C}$ is necessary to prevent the texture of fish gels from deteriorating (Kim \& Park, 2000). Hsu \& Chung (1998), indicated a positive correlation between meat hardness and total food assessment, which means that consumers generally prefer harder texture for meat. However, higher values of the parameters measured in TPA (hardness, cohesiveness, springiness, and chewiness) do not necessarily mean better quality. Good textural qualities of meatballs should be determined together with a sensory test in order to establish the most suitable range preferred by consumers.

\section{CONCLUSION}

Chicken meat prepared as meatballs will fulfill the consumer convenience criteria for 70 days if heat treated at $90^{\circ} \mathrm{C}$ for 10 minutes and stored at $+2^{\circ} \mathrm{C}$.

\section{ACKNOWLEDGMENTS}

This study is supported by the Cumhuriyet University Scientific Research Projects Unit (Project No: M-431) and summarized from a Post Graduate Thesis.

\section{REFERENCES}

AOAC. Official methods of analysis of association of official chemists. $15^{\text {th }}$ ed. Arlington; 1990.

Bourne MC. Texture profile analysis. Food Technology 1978;33:62-66.

Carlin F. Guin enterobacterias retiere. In: Choma C, Schmitt P, Nguyen C. A Fair collaborative programme: research on factors allowing a risk assessment of spore-forming pathogenic bacteria in cooked chilled foods containing vegetables. Proceedings of the 3th European Symposium on Sous-vide; 1999; Leuven. Belgium. p.53-70.

Cremer ML, Yum TKK, Banwart GJ. Time, temperature, microbial and sensory quality assessment of chicken and noodles in a hospital foodservice system. Journal of Food Science 1985;50:891-896. 
Çiftçioglu G. İstanbul piyasasındaki kıyma, sucuk ve tavuk eti örneklerinde listeria türlerinin mevcudiyetinin araştırılması [tezi]. İstanbul: Üniv. SağlıkBilimleriEnstitüsü; 1992. p.1-47.

Doğan is, Küçüköner E, Kılınççeker O, Meral R. Kaplama malzemesi olarak galeta unlarının bazı kalite özelliklerinin belirlenmes. Dünya Gıda 2005;1:77-83.

Diaz P, Nieto G, GarridoMD, Banon S. Microbial, physical, chemical and sensory spoilage during the refrigerated storage of cooked pork loin processed by the sous vide method, Meat Science 2008;80:287-292.

Erol i. Gıda hijyenive mikrobiyolojisi. Ankara: Pozitif Matbaacılık; 2007. p.244-249.

Gonzalez-FandosEMC, Garcia-Lınares A, Villaniro-Rodriguez MT, Garcia Arias MC. Evaluation of the microbiological safety and sensory quality of rainbow trout (Oncorhynchusmykiss) processed by the sous vide method. Food Microbiology 2004,21:193-201.

Grayl, Pearson AM. Rancidity and warmed-over-flavour. In: Pearson AM, Dutson TR, editors. Advances in meat research. Restructured meat and poultry products. New York: Van Nostrand Reinhold; 1987. p.221-269.

Grigioni GM, Margaría CA, Pensel NA, Sánchez G, Vaudagna SR. Warmedover flavor analysis in low temperature-long time processed meat by an "electric nose". Meat Science 2000;56:221-228.

Guerzoni ME, Gianotti A, Lopez CC. Effect of some process variables on safety and shelf-life of "sous vide" cooked foods Proceedings of the 3th European Symposium on Sous-vide; 1999; Leuven. Belgium. p.253266.

Halkman AK. Gıda mikrobiyolojisi uygulamaları merck. Ankara: Başak Matbaaclik; 2005. p.358.

Harrigan WF. Laboratory methods in food microbiology. London: Academic Press; 1998.

Hasipek S, Aktaş N. Ülkemizde tavuk eti ve yumurtanın insan beslenmesindeki yeri ve önemi. Uluslararası Tavukçuluk Kongresi; 1991 May 22-25; İstanbul. Turquia. p. 26-35.

Hsu SY, Chung HY. Effects of processing factors on qualities of emulsified meatball. J. Food Eng., 1998;36: 337-347.

Hunt MC, Kropf DH. Color and appearance. Van Nostrand; 1987. p.13-18.
ICMSF. Microorganisms in foods. Their significance and methods of enumeration. 2nd ed. Toronto: University of Toronto Press; 1978.

Kim B, Park J. Surimi and surimi seafood. New York; 2000. p.313.

Kurtcan Ü, Gönül M. Gıdaların duyusal değerlendirilmesinde puanlama metodu, Ege Üniversitesi Mühendislik Fakültesi Dergisi, Seri B, Gıda Mühendisliği 1987;5:137-146.

Light N, Hudson P, Williams R, Barret J, Schafheitle J. A pilot study on the use of sous vide vacuum cooking as a production system for high quality foods in catering. International Journal of Hospitality Management $1988 ; 7: 21-27$.

Nyati $\mathrm{H}$. An evaluation of the effect of storage and processing temperatures on the microbiological status of sous vide extended shelf-life products. Food Control 2000;11(6):471-476.

Pearson D. The chemical analysis of foods. London: Churchill Living-stone; 1976. p.6- 106

Roldan M, Antequera T, Martin A, Mayoral Al, Ruiz J. Effect of different temperature-time combinations on physicochemical, microbiological, textural and structural features of sous-vide cooked lamb loins. Meat Science 2012;93(3):572-578

Rosnes JT, Kleiberg $H$, Bergslein $H$, Vidvei J. Microbiological safety of two sous vide fish based meals. Proceedings of the 3th European Symposium on Sous-vide; 1999; Leuven. Belgium. p.195-204.

SAS Institute. Statistical Analysis System -graph Software: version 6.1, Cary, NC; 1996

Schafheitle JM, Light ND. Technical note: sous vide preparation and chilled storage of chicken ballotine. International Journal of Food Science and Technology 1989;24:199-205.

Simpson MV, Smith JP, Simpson BK, Ramaswamy H, Dodds KL. Storage studies on a sous videspaghetti and meat sauce product. Food Microbiology 1994;11:5-14.

Türk Gıda Kodeksi. Mikrobiyolojik kriterler enterobacteriaceaeliği. Ankara: Gıda Tarımve Hayvancılık Bakanlığı; 2009a.

Wang SH, Chang MH, Chen TC. Shelf-life and microbiological profiler of chicken wing products following sous vide treatment. International Journal of Poultry Science 2004;3(5):326-332. 